\title{
Bowhead Whale Distribution and Feeding near Barrow, Alaska, in Late Summer 2005-06
}

\author{
SUE E. MOORE, ${ }^{1}$ J.C. “CRAIG” GEORGE, ${ }^{2}$ GAY SHEFFIELD, ${ }^{3}$ JOSHUA BACON ${ }^{2}$ and CARIN J. ASHJIAN ${ }^{4}$
}

(Received 20 May 2008; accepted in revised form 24 August 2009)

\begin{abstract}
Aerial surveys for bowhead whales were conducted in conjunction with oceanographic sampling near Barrow, Alaska, in late summer of 2005 and 2006. In 2005, 145 whales were seen, mostly in two distinct aggregations: one (ca. 40 whales) in deep water in Barrow Canyon and the other (ca. 70 whales) in very shallow $(<10 \mathrm{~m})$ water just seaward of the barrier islands. Feeding behaviours observed in the latter group included whales lying on their sides with mouths agape and groups of 5-10 whales swimming synchronously in turbid water. In 2006, 78 bowheads were seen, with ca. 40 whales feeding in dispersed groups of 3-11 whales. Feeding behaviours observed included surface skimming, echelon swimming, and synchronous diving and surfacing. Surfacing behaviour included head lunges by single animals and groups of $2-4$ whales. Of 29 whales harvested at Barrow, 24 had been feeding. Euphausiids were the dominant prey in 2006 (10 of 13 stomachs), but not in 2005 ( 4 of 11 stomachs). Copepods were the dominant prey in the stomachs of three whales harvested near Barrow Canyon in 2005. Mysiids were the dominant prey in four stomachs, isopods in two, and amphipods in one although these taxa were not routinely captured during plankton sampling conducted in the weeks prior to the autumn harvest.
\end{abstract}

Key words: bowhead whale, feeding, functional anatomy, zooplankton, western Arctic, Beaufort Sea, aerial surveys

RÉSUMÉ. Des levés aériens visant les baleines boréales ont été réalisés conjointement avec de l'échantillonnage océanographique près de Barrow, en Alaska, vers la fin des étés 2005 et 2006. En 2005, 145 baleines ont été aperçues et celles-ci relevaient principalement de deux groupes distincts : un groupement (d'une quarantaine de baleines) se trouvait dans les eaux profondes du canyon de Barrow et l'autre groupement (d'environ 70 baleines) dans des eaux très peu profondes $(<10 \mathrm{~m})$ du côté de la mer des îles-barrières. Le comportement alimentaire observé au sein de ce dernier groupe était tel que certaines baleines s'étendaient sur le côté la gueule grande ouverte pendant que des groupes de 5 à 10 baleines nageaient de manière synchronisée dans l'eau trouble. En 2006, 78 baleines boréales ont été aperçues, dont une quarantaine de baleines s'alimentaient dans des groupes dispersés de 3 à 11 baleines. Parmi les comportements alimentaires observés, notons l'écrémage, la natation en échelons de même que la plongée et le surfaçage synchronisés. Quant au comportement de surfaçage, il prenait la forme de longes de tête par des baleines individuelles et des groupes de 2 à 4 baleines. Parmi les 29 baleines récoltées à Barrow, 24 avaient mangé. En 2006, la proie dominante était l'euphausia (dans 10 des 13 estomacs), ce qui n'était pas le cas en 2005 (dans 4 des 11 estomacs). En 2005, les copépodes constituaient la proie dominante des estomacs de trois baleines récoltées près du canyon de Barrow. Les mysis représentaient la proie dominante de quatre estomacs, tandis que les isopodes dominaient dans deux estomacs et les amphipodes dans un estomac, bien que ces taxons n'aient pas été invariablement prélevés dans le cadre de l'échantillonnage du plancton réalisé au cours des semaines précédant la récolte d'automne.

Mots clés : baleine boréale, alimentation, anatomie fonctionnelle, zooplancton, Ouest de l’Arctique, mer de Beaufort, levés aériens

Traduit pour la revue Arctic par Nicole Giguère.

\section{INTRODUCTION}

The Bering-Chukchi-Beaufort (BCB) population of bowhead whales (Balaena mysticetus) migrates annually from northern Bering Sea wintering areas to summering areas in the Canadian Beaufort Sea (Moore and Reeves, 1993; Moore et al., 2000). This population has been studied intensively for over three decades because of concerns about its status (e.g., Rugh et al., 2003; George et al., 2004) and about the effects of underwater noise from offshore industrial activities both on the whales' behaviour and on the outcome of the subsistence hunt (e.g., Richardson and Malme, 1993). The dramatic loss of sea ice in the Pacific-Arctic region during the past decade (e.g., Serreze et al., 2007; Wang and Overland, 2009) has compounded these concerns, as vessel traffic and offshore industrial activities have increased concomitantly with sea-ice reduction (Ragen et al., 2008). In addition, loss of sea ice has prompted questions regarding

\footnotetext{
${ }^{1}$ NOAA/Fisheries, Office of Science \& Technology, 7600 Sand Point Way NE, Building 3, Seattle, Washington 98115, USA; Sue.Moore@noaa.gov

${ }^{2}$ North Slope Borough, Department of Wildlife Management, PO Box 69, Barrow, Alaska 99723, USA

${ }^{3}$ Alaska Department of Fish and Game, Pouch 1148, Nome, Alaska 99762, USA

${ }^{4}$ Department of Biology, Woods Hole Oceanographic Institution, Woods Hole, Massachusetts 02543, USA

(C) The Arctic Institute of North America
} 
the potential for habitat alteration that may further challenge, or benefit, the BCB bowhead whale population (Moore and Laidre, 2006; Bluhm and Gradinger, 2008).

The annual migration of bowhead whales past Barrow, Alaska, has provided subsistence hunting opportunities to Iñupiat whalers for roughly 2000 years (Stoker and Krupnik, 1993). Whales consistently pass close to Barrow from late April through June and again from late September through October, providing two opportunities for subsistence harvests each year (e.g., Suydam et al., 1995). Bowheads commonly feed during the westward autumn migration (Lowry et al., 2004), and hunting is facilitated when whales linger to forage near Barrow. However, little is known about the mechanisms that foster localized prey aggregations, which contribute to hunting success by attracting whales. Similarly, the timing of bowhead whale arrival and residency in waters near Barrow is not well documented. Opportunistic records show that bowheads were seen near Barrow throughout summer during the 1980s, but reports were sporadic and whale numbers low (Moore, 1992). While summertime reports from hunters of bowhead sightings near Barrow have become more commonplace since the mid-1990s (J.C. George, unpubl. data), whether these whales arrive from the eastern Beaufort Sea or reside near Barrow over summer is unknown.

In 2004, a multidisciplinary scientific team was funded to study the coastal ecosystem near Barrow as part of the National Science Foundation's Study of Northern Alaska Coastal System (SNACS) program. Oceanographic sampling and aerial surveys were conducted along transect lines near Barrow in late August and early September of 2005 and 2006 to (1) describe water mass types and plankton communities; (2) identify exchange of water and material between the lagoon, shelf, and offshore bathymetric domains; (3) investigate biological and physical mechanisms of zooplankton aggregation; and (4) describe the arrival, distribution, and behaviour of bowhead whales. Results of the first three aspects of the study are provided in Ashjian et al. (2010). This paper focuses on the fourth objective and includes information on local zooplankton occurrence as indicated by stomach contents of harvested whales.

\section{METHODS}

\section{Surveys and Mapping}

Aerial surveys were conducted in late summer of 2005 and 2006 along lines designed for oceanographic sampling across Barrow Canyon and over the narrow continental shelf between Barrow and Smith Bay (Ashjian et al., 2010: Fig. 2). In both years, surveys were conducted from high wing aircraft flying at roughly $185 \mathrm{~km} / \mathrm{h}$ (100 kts) between 315 and $470 \mathrm{~m}(1000-1500 \mathrm{ft})$ altitudes. Two primary observers maintained a continuous watch through bubble windows, noting abrupt changes in visibility such as fog or glare, sea surface conditions (i.e., fronts and sea-ice cover), the time and location of marine mammal sightings, and any deviations from the survey course. The pilot and a third observer assisted the primary observers in spotting bowhead whales. In 2005, surveys were flown in an Aero Commander, specially outfitted with a belly port that enabled identificationquality photographs to be obtained whenever groups of bowhead whales were encountered. In 2006, surveys were conducted from a Twin Otter, following the U.S. Minerals Management Service (MMS) Bowhead Whale Aerial Survey (BWASP) survey protocol (Monnett and Treacy, 2005). Flights were conducted along the SNACS track lines and, on 3 and 5 September, along BWASP transects east of the primary study area, which provided broader spatial sampling of bowhead whale distribution in late summer. In both years, photographs of bowhead whales were taken to document group size and behaviours using a Canon EOS 30D SLR with an $85 \mathrm{~mm}$ image-stabilized lens. Subsequently, survey effort, bowhead whale distribution, and the distribution of harvested whales were plotted on maps that included the International Bathymetric Chart of the Arctic Ocean (IBCAO) bathymetric database supported by ArcView ${ }^{\mathrm{TM}}$.

\section{Collection and Analysis of Stomach Contents}

The SNACS study fostered continuation of the bowhead stomach contents data series initiated in 1976, using the same procedures as reported in Lowry et al. (2004). In brief, the stomachs of whales landed at Barrow during the autumn subsistence hunt in 2005 and 2006 were examined as soon as possible, often within a few hours after the animal was brought to shore. When possible, a sample of contents was immediately collected from the forestomach and a crude estimate made of stomach fullness (i.e., trace, $1 / 4,1 / 2,3 / 4$, or full). Bowhead whales with empty stomachs were coded as not feeding, while those with at least 10 prey items were coded as feeding. If a very small amount of prey (fewer than 10 items) was present, the feeding status of the whale was recorded as uncertain. Items such as algae, feathers, and pebbles were not considered prey, and whale stomachs that contained milk were not included in the analysis. Stomach contents samples were then frozen for later examination.

In the laboratory, prey samples were gently rinsed in freshwater on a $1.0 \mathrm{~mm}$ screen with a $0.50 \mathrm{~mm}$ screen layered underneath, then sorted macroscopically into major taxonomic groups. Sorted samples were then examined microscopically and identified to the lowest taxonomic level possible by one of the authors (Gay Sheffield) and by taxonomy experts at the University of Alaska, Fairbanks. Voucher specimens were stored in $70 \%$ isopropyl alcohol. Then, the water displacement volume of sorted prey items was weighed to the nearest $0.1 \mathrm{ml}$ in graduated cylinders, with no correction for the state of digestion. Any sample weighing less than $1.0 \mathrm{~g}$ was excluded from the volumetric analysis. Finally all data were entered into the electronic Alaska Department of Fish and Game (ADF\&G) database of bowhead stomach contents for whales harvested in Alaska. 
TABLE 1. Summary of bowhead sightings and behaviour during 13 aerial surveys in the SNACS study area and two (indicated by asterisks) in the MMS-BWASP study area near Barrow, Alaska, in 2005 and 2006.

\begin{tabular}{|c|c|c|c|c|}
\hline Year & Date & No. of Sightings & No. of Whales & Comments \\
\hline \multirow[t]{9}{*}{2005} & 27 August & 0 & 0 & - \\
\hline & 30 August & 1 & 1 & Large whale rapidly swimming west \\
\hline & 31 August & 1 & 1 & Large whale rapidly swimming west \\
\hline & 01 September & 0 & 0 & - \\
\hline & 02 September & 0 & 0 & - \\
\hline & 04 September & 1 & 1 & Single whale near Smith Bay \\
\hline & 06 September & 3 & 5 & One group of 3 whales and 2 single whales in Barrow Canyon \\
\hline & 08 September & 111 & 133 & $\begin{array}{l}\text { Two large aggregations of feeding bowheads; ca. } 70 \text { whales off the shore of Dease Inlet and ca. } \\
40 \text { whales in Barrow Canyon }\end{array}$ \\
\hline & 09 September & 4 & 4 & Two large and two small whales. Very poor visibility—had to truncate flight \\
\hline Subtotal & 9 surveys & 121 & 145 & \\
\hline \multirow[t]{6}{*}{2006} & 01 September & 0 & 0 & - \\
\hline & 02 September & 1 & 2 & Smaller whale following a large whale rapidly swimming west \\
\hline & 03 September* & 5 & 5 & Five lone whales seen east of SNACS study area, all swimming west (see Fig. 2) \\
\hline & 04 September & 16 & 37 & Groups of 3 to 11 whales feeding from shelf to slope north of Cooper Island \\
\hline & 05 September* & 15 & 23 & $\begin{array}{l}\text { Two groups ( } 8 \text { whales) feeding north of Cooper Island. Eleven sightings of } 14 \text { whales more than } \\
200 \mathrm{~km} \text { east of SNACS area, swimming west, and a single whale (see Fig. 2) }\end{array}$ \\
\hline & 06 September & 8 & 11 & Small groups near Cooper Island and in Barrow Canyon \\
\hline Subtotal & 6 surveys & 45 & 78 & \\
\hline Total & 15 surveys & 166 & 223 & \\
\hline
\end{tabular}

\section{RESULTS}

\section{Temporal and Spatial Distribution}

Fifteen aerial surveys were completed over the two seasons: nine surveys between 27 August and 9 September 2005, and six surveys between 1 and 6 September 2006 (Table 1). In 2005, few whales were seen on the first seven surveys, conducted from 27 August through 6 September. Then, quite surprisingly, two bowhead whale aggregations were discovered in the study area on 8 September 2005 (Fig. 1). The whales were predominantly in two dense groups, one of ca. 70 animals in very shallow water just offshore of the barrier islands and a second of ca. 40 whales in deep water of Barrow Canyon. Only four bowheads were seen on 9 September, but extremely poor weather conditions caused the flight to be abruptly truncated after only a cursory survey of the coastal area.

Although fewer whales were seen in 2006, the temporal pattern of sightings was similar to the 2005 pattern. Few bowheads were seen on the first three surveys conducted from 1 to 3 September (Table 1). Then, on 4 September, 37 whales were seen in the study area (Fig. 2), feeding in dispersed groups of 3-11 whales, roughly $40 \mathrm{~km}$ northeast of Barrow. Feeding whales were encountered in this same general area on 5-6 September, and they persisted there at least through 27 October, as documented on surveys flown in support of industry (Ireland et al., 2008). It is notable that on 5 September, 11 sightings of 14 westward-swimming bowhead whales were distributed along the outer shelf and continental slope waters roughly $200 \mathrm{~km}$ east of the SNACS study area. These sightings, and those on 3 September, demonstrate that bowheads were distributed across the Alaskan Beaufort Sea in early September, suggesting that the autumn migration was underway at that time.

\section{Feeding Behaviours}

Observed feeding behaviours varied somewhat by year. In 2005, whales in the largest aggregation adjacent to the barrier islands often swam side by side in very shallow $(<20 \mathrm{~m})$ milky-silty water (Fig. 3a). Whales occurred in pairs or in small groups of 3-7 animals, with individuals roughly a body-width or less apart and diving synchronously. Most had mud streaming from their heads. One whale was observed defecating, and another was lying on its side at the surface with its mouth agape and lower jaw completely distended (Fig. 3b). In 2006, in contrast, there were several surface-active feeding groups composed of 3-11 whales. Whales swam in all directions, milled in small groups, swam in pairs and echelons (Fig. 3c), and dived or surfaced simultaneously. Synchronous surfacing was sometimes very dynamic: single whales, pairs, and groups of 3 to 4 animals lunged upwards out of the water with their heads together in a manner similar to that of cooperatively feeding humpback whales (Megaptera novaeangliae). Head lunges were seen only on 4 and 6 September, among the loose aggregation of whales feeding near Cooper Island. Available survey time did not allow for detailed observations of group composition, inter-lunge intervals, or respiration parameters. In both years, whales that appeared to be feeding in the Barrow Canyon swam slowly, milled, and dived synchronously.

\section{Stomach Contents of Harvested Whales}

The stomachs of 29 bowhead whales taken during the subsistence hunt were examined, 12 in 2005 and 17 in 2006 (Table 2). The hunt occurred a week or more after the SNACS field sampling was completed in both years. In 


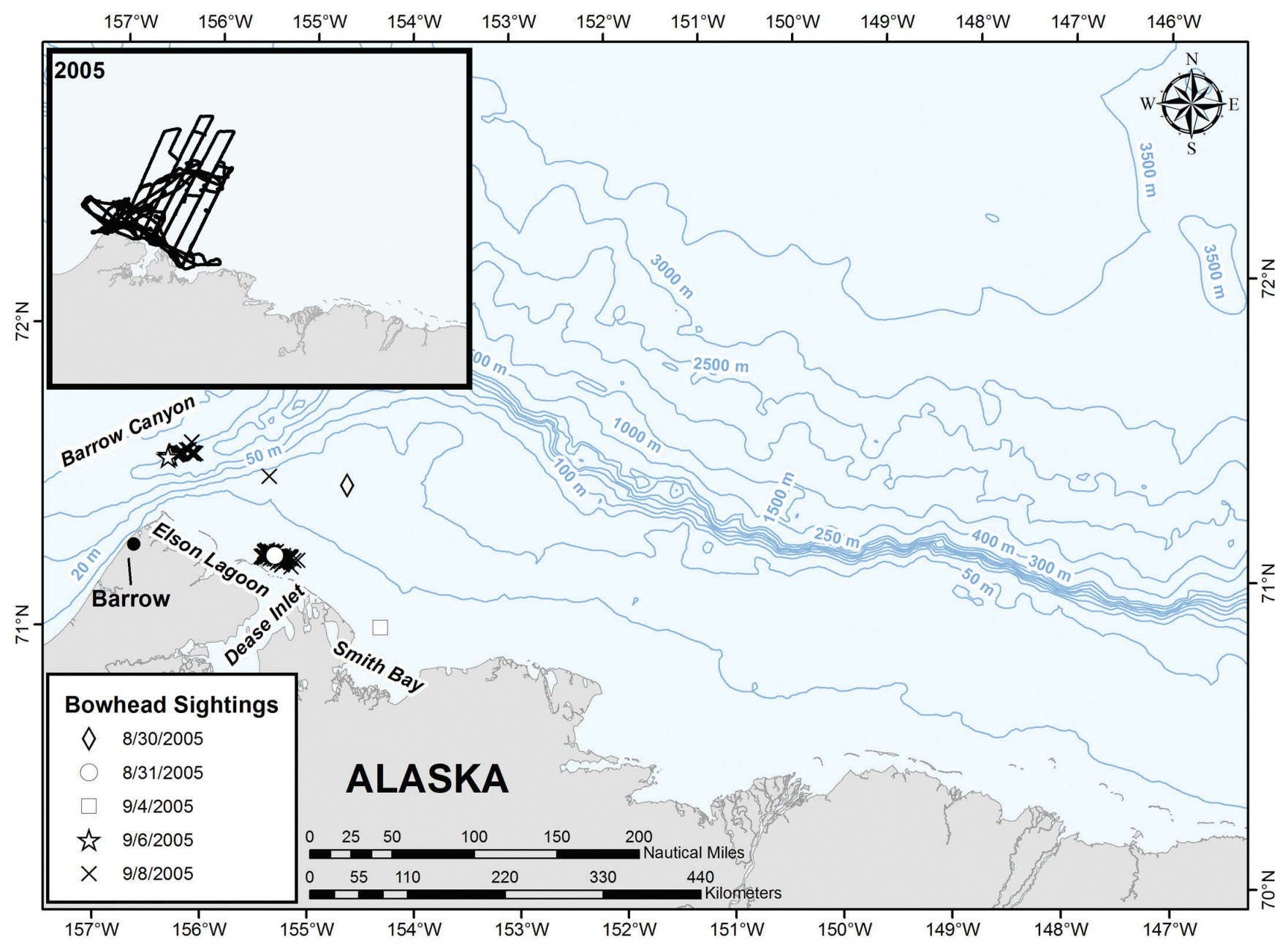

FIG. 1. Aerial survey effort and bowhead whale distribution in 2005.

2005, when the harvest occurred from 1 to 5 October, 11 whale stomachs were coded as "feeding" and one as "not feeding." In 2006, when the harvest occurred from 25 September to 3 October, 13 whale stomachs were coded as "feeding," two as "not feeding," and one as "uncertain," and one stomach contained milk. Lengths of harvested whales ranged from $6.3 \mathrm{~m}$ to $13.3 \mathrm{~m}$, suggesting they were juveniles or young adults. There was no significant difference (t-test, $p<0.05$ ) between the mean whale lengths in 2005 $(8.8 \pm 1.0 \mathrm{~m}$, mean $\pm \mathrm{SD})$ and in $2006(9.5 \pm 1.7 \mathrm{~m})$.

In 2005, most of the examined whales were harvested in deeper waters (50 m or more) in Barrow Canyon, and only four whales were taken on the shelf (Fig. 4). Conversely, most whales examined in 2006 were harvested on the shelf, in shallower waters (20 m or less) (Fig. 5). In both years, only about half the whales examined had full stomachs, and there was a marked difference between years in the occurrence of euphausiids as the dominant prey (Table 2; Fig. 6). In 2005, euphausiids were the dominant prey by volume in only four $(36 \%)$ of the 11 stomachs that contained prey, while in 2006, euphausiids were dominant in 10 (77\%) of 13 stomachs. Copepods were the dominant prey in the stomachs of three whales harvested in 2005 (Table 2, Fig. 6a).
Mysiids were the dominant prey in three stomachs in 2005 and in one stomach in 2006. Amphipods were the dominant prey in one stomach and a significant portion of the prey found in two others in 2006 (Table 2; Fig. 6b), and isopods were the dominant prey in one stomach in each year. Prey that occurred in less than $10 \%$ of the whale stomachs examined included primarily benthic or epibenthic taxa such as clam, snail, priapulid worm, echiurid worm, polychaete worm, ostrocod, and small fish. It is likely that at least some of these occasional prey items were ingested incidentally to the primary forage target.

\section{DISCUSSION}

In both 2005 and 2006, bowhead whales were observed feeding near Barrow, Alaska, in early September, roughly two weeks earlier than feeding aggregations reported there in the 1970s to 1990s. Whales were in larger and denser aggregations in 2005, with most whales either in very shallow water offshore of the barrier islands, or in Barrow Canyon. In 2006, some whales again occurred in Barrow Canyon, but most were distributed in smaller groups on the 


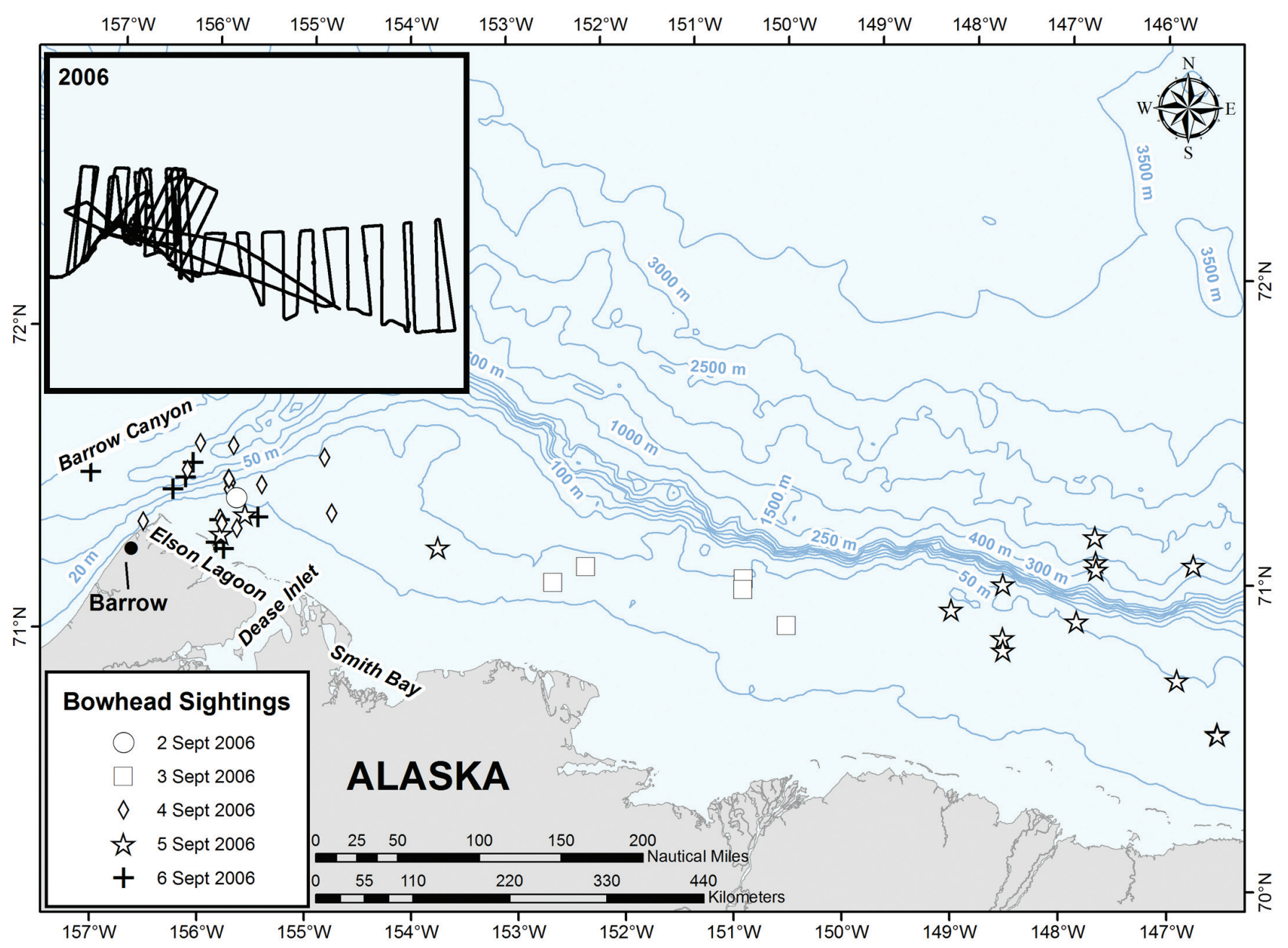

FIG. 2. Aerial survey effort and bowhead whale distribution in 2006.

shelf north of Cooper Island, roughly $40 \mathrm{~km}$ northeast of Barrow. In both years, surveys on which groups of feeding whales were seen were preceded by surveys when no whales were seen, or only lone whales or a whale pair swimming rapidly westward. Euphausiids were the dominant prey by volume in $36 \%$ of the stomachs that contained prey in 2005 and in $77 \%$ of the stomachs in 2006 . These indices are both lower than the $86 \%$ ( 55 of 64 whales) of bowhead stomachs that held over $50 \%$ euphausiid contents reported by Lowry et al. (2004).

The contrast in prey found in stomachs roughly corresponded with differences in harvest locations: in 2005, stomachs contained a more diversified diet, and most whales were taken from water deeper than $50 \mathrm{~m}$ near Barrow Canyon, while in 2006, most whales were feeding on euphausiids and were harvested from shelf waters $(<20 \mathrm{~m}$ deep) northeast of Barrow. Plankton tows completed a few weeks before the whaling season contained primarily copepods, with elevated abundances of euphausiids on some dates (C. Ashjian and R.G. Campbell, unpubl. data). Mysiids, amphipods, and isopods were the dominant prey by volume in seven bowhead stomachs, although these species were not routinely captured during zooplankton sampling.
Their presence in the whale stomachs must mean either that these prey species occur episodically, or that whales had been feeding near the bottom on epibenthic zooplankton that could not be sampled during the net tows (Ashjian et al., 2010).

While this is not the first detailed report of bowhead whales feeding near Barrow, the SNACS study did provide an opportunity for a systematic survey of the coastal waters there in late August and early September. Although BWASP surveys have been conducted in the Alaskan Beaufort Sea each autumn since 1979, sampling near Barrow rarely occurs before mid- to late September (see annual reports by Treacy for 1988 to 1998 and 2000, cited in Monnett and Treacy, 2005). For example, from BWASP surveys, Landino et al. (1994) report bowhead aggregations totaling $56-104$ whales feeding over a $277 \mathrm{~km}^{2}$ area roughly $35 \mathrm{~km}$ northeast of Barrow from 17 to 19 October 1992; while Ljungblad et al. (1986) describe a group of roughly 45-70 whales feeding east of Point Barrow on 22-24 September 1984. Notably, when BWASP surveys were conducted near Barrow in late summer, a single whale in 2002 and 13 bowheads in 2004 were noted as feeding (Monnett and Treacy, 2005). Overall, 144 whales were reported as feeding during 

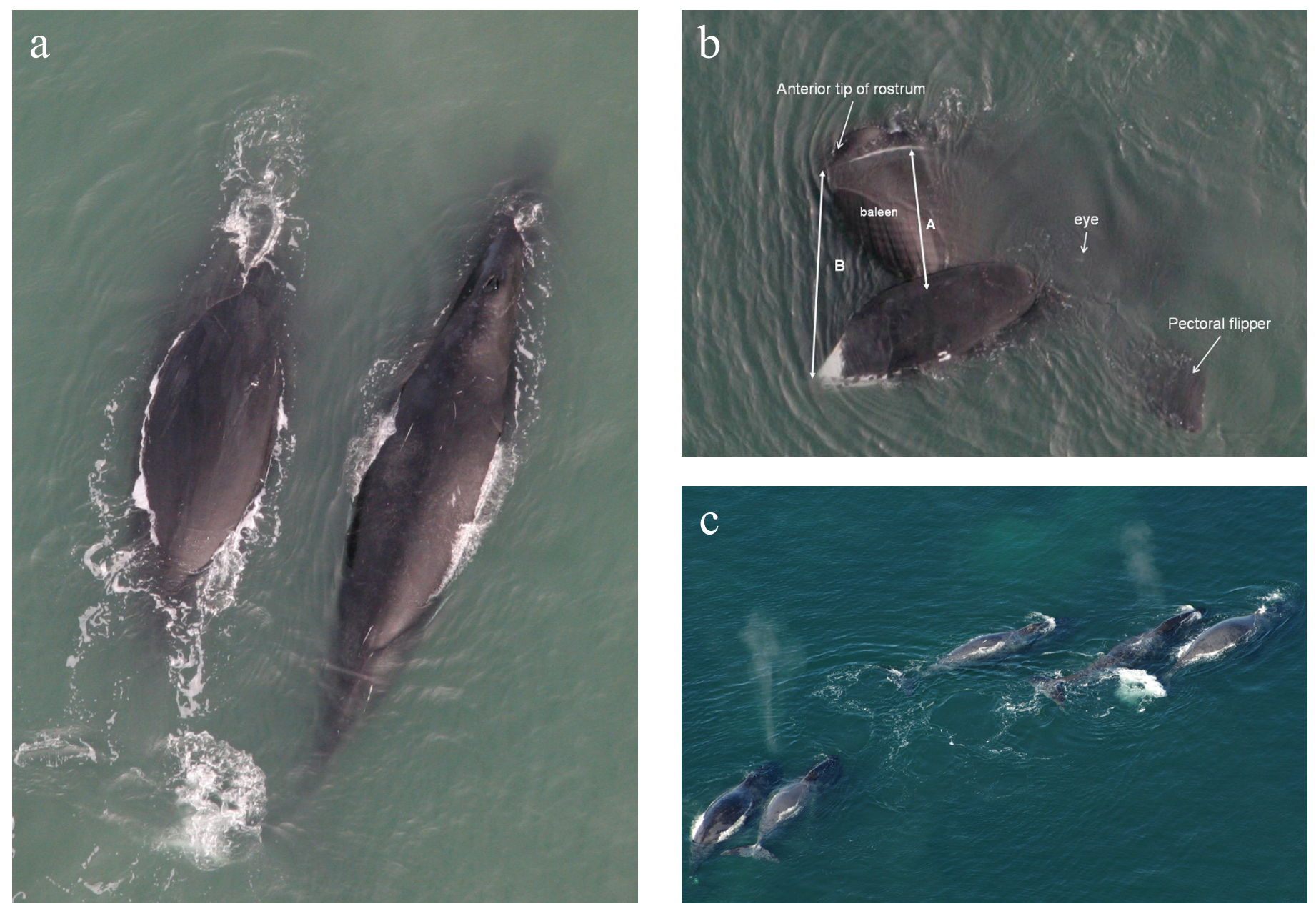

FIG. 3. Bowhead whales feeding: (a) Two bowhead whales feeding side by side in shallow water. (b) A large bowhead with mouth agape in the feeding aggregation just northwest of Dease Inlet on 8 September 2005. Body parts are labeled to orient the reader. Note that the maximum baleen length (arrow A) is shorter than the maximum mouth gape (arrow B), which has implications for estimation of prey ingestion rates (see text). (c) Five bowhead whales feeding in semi-echelon formation offshore of Cooper Island on 4 September 2006.

BWASP surveys in 2004, and most of them were seen in or near the SNACS study area between 16 and 30 September. Similarly, reports from opportunistic sightings in the 1970 s include an aggregation of $80-100$ bowhead whales feeding east of Barrow on 20 September 1974, "another large aggregation" seen "in the same general area" in September 1975 (Burns, 1993:754-755), and 47 whales counted in the area on 21 September 1976 (Lowry and Frost, 1984). Reports were consistent enough that by 1984, an area from Point Barrow east to approximately Pitt Point (ca. $156^{\circ} 10^{\prime} \mathrm{W}$ to $153^{\circ} \mathrm{W}$ ), was identified as one of two feeding areas for bowheads in the Alaskan Beaufort Sea in September and October (Lowry, 1993). So, observations from the SNACS study, combined with those noted above and the summary of summer sightings from 1984 to 1991 (Moore, 1992), emphasize the importance of waters near Barrow for bowhead feeding and advance the period of occupancy from autumn to late summer.

With the exception of head lunging, the manner of bowhead whale feeding was similar to that described for whales feeding elsewhere in the Beaufort Sea (Würsig and Clark, 1993). Whales fed in the water column in the deep water of Barrow Canyon and skimmed the surface, sometimes in echelon formations, in the shallow coastal areas. Head lunging was observed on two occasions in 2006, when euphausiids dominated prey found in stomach contents. This active surfacing by one or two to four whales in synchrony was reminiscent of cooperative feeding by humpback whales. Würsig and Clark (1993) note that slow-moving bowhead whales feeding on rapid-swimming evasive euphausiids might benefit by adopting echelon swimming - essentially to create a wall of whales against which the prey can be caught. Head lunging, which was seen in the vicinity of whale echelons, may be a secondary means to capture evasive fast-moving euphausiid prey.

With regard to the mechanics of feeding, the photograph of the whale with its mouth agape is similar to one published in Thomson (2002), but shows the lower jaw even more distended so that most of the anterior portion of the baleen rack is not enclosed by the lips (Fig. 3b). Thomson (2002:22) estimated the cross-sectional filtering area of the mouth as a triangle using "the inner width of the mouth and the maximum baleen length." We suggest that the true cross-sectional area through which water enters the mouth 
TABLE 2. Stomach status and contents for bowhead whales harvested at Barrow, Alaska in autumn $2005(\mathrm{n}=12)$ and $2006(\mathrm{n}=17)$. Stomach fullness is given as TR (trace), 1/4, 1/2, 3/4, and F (full); a question mark (?) indicates that fullness was not estimated.

\begin{tabular}{|c|c|c|c|c|c|c|}
\hline ID No. & Date & Sex & Length (m) & Stomach Status & Dominant Prey by Volume & Stomach Fullness \\
\hline \multicolumn{7}{|l|}{2005} \\
\hline 05B17 & 1 October & $\mathrm{M}$ & 8.3 & Feeding & Euphausiid & $\mathrm{TR}$ \\
\hline $05 \mathrm{~B} 18$ & 1 October & $\mathrm{F}$ & 9.2 & Feeding & Copepod & $\mathrm{F}$ \\
\hline 05B19 & 2 October & $\mathrm{M}$ & 11.1 & Feeding & Copepod & $\mathrm{F}$ \\
\hline $05 \mathrm{~B} 20$ & 2 October & $\mathrm{M}$ & 8.6 & Feeding & Euphausiid & $\mathrm{F}$ \\
\hline $05 \mathrm{~B} 21$ & 3 October & $\mathrm{F}$ & 8.8 & Feeding & Copepod & $1 / 2$ \\
\hline 05B22 & 3 October & $\mathrm{M}$ & 7.4 & Feeding & Mysiid & $1 / 4$ \\
\hline $05 \mathrm{~B} 23$ & 3 October & $\mathrm{F}$ & 8.7 & Feeding & Euphausiid & $\mathrm{TR}$ \\
\hline 05B24 & 4 October & $\mathrm{M}$ & 9.5 & Feeding & Mysiid & $\mathrm{F}$ \\
\hline $05 \mathrm{~B} 26$ & 4 October & $\mathrm{M}$ & 12.2 & Not Feeding & - & - \\
\hline $05 \mathrm{~B} 27$ & 5 October & $\mathrm{M}$ & 8.6 & Feeding & Euphausiid & TR \\
\hline $05 \mathrm{~B} 28$ & 5 October & $\mathrm{F}$ & 8.0 & Feeding & Isopod & TR \\
\hline $05 \mathrm{~B} 29$ & 5 October & $\mathrm{F}$ & 9.4 & Feeding & Mysid & $1 / 4$ \\
\hline \multicolumn{7}{|l|}{2006} \\
\hline 06B4 & 25 September & $\mathrm{M}$ & 8.6 & Feeding & Mysiid & $1 / 2$ \\
\hline 06B5 & 25 September & $\mathrm{M}$ & 8.8 & Uncertain & - & - \\
\hline 06B6 & 25 September & $\mathrm{M}$ & 13.3 & Not Feeding & - & - \\
\hline 06B7 & 26 September & $\mathrm{M}$ & 8.9 & Not Feeding & - & - \\
\hline 06B8 & 26 September & $\mathrm{M}$ & 10.3 & Feeding & Euphausiid & TR \\
\hline 06B9 & 28 September & M & 7.8 & Feeding & Isopod & $\mathrm{F}$ \\
\hline 06B10 & 29 September & M & 6.3 & Nursing & Milk & - \\
\hline 06B11 & 29 September & $\mathrm{M}$ & 9.3 & Feeding & Euphausiid & TR \\
\hline $06 \mathrm{~B} 12$ & 29 September & $\mathrm{F}$ & 8.8 & Feeding & Euphausiid & ? \\
\hline $06 \mathrm{~B} 13$ & 30 September & $\mathrm{F}$ & 8.9 & Feeding & Amphipod & $1 / 2$ \\
\hline 06B14 & 30 September & $\mathrm{F}$ & 8.5 & Feeding & Euphausiid & TR \\
\hline $06 \mathrm{~B} 15$ & 30 September & $\mathrm{F}$ & 10.1 & Feeding & Euphausiid & $\mathrm{F}$ \\
\hline $06 \mathrm{~B} 16$ & 1 October & $\mathrm{M}$ & 9.4 & Feeding & Euphausiid & $\mathrm{F}$ \\
\hline 06B17 & 1 October & $\mathrm{M}$ & 10.5 & Feeding & Euphausiid & $\mathrm{F}$ \\
\hline 06B19 & 2 October & $\mathrm{F}$ & 9.5 & Feeding & Euphausiid & $\mathrm{F}$ \\
\hline 06B20 & 2 October & $\mathrm{M}$ & 9.6 & Feeding & Euphausiid & $3 / 4$ \\
\hline 06B2 & 12 October & M & 12.8 & Feeding & Euphausiid & $?$ \\
\hline
\end{tabular}

should be calculated in a manner similar to that of Thomson (2002), but using a "diamond" shape as the maximum distance between the tip of the rostrum and the distal tip of the lower jaw (Fig. 3b, Arrow B), rather than maximum baleen length (Fig 3b, Arrow A). Calculated by this method, the area of the mouth might be considerably larger than Thomson's estimates, which has significant implications for prey ingestion rates. Specifically, Lambertsen et al. (2005:348) suggest that with the mouth fully open, the "lower lip creates a gutter for water flow," and the convex portion of the baleen rack has a "Venturi effect as water flows along the outside of the baleen rack," possibly enhancing feeding efficiency. St. Lawrence Island hunters report having seen this "wide-mouthed" behaviour associated with a vertical rise out of the water, with mouth agape so that the baleen is "free of the lips." A "strange noise" is reported with the closing of the mouth, and it has been suggested that this behaviour has to do with "cleaning the baleen" (Chester Noongwook and Tom Alowa, pers. comm. 2007).

The SNACS study addressed this central question: What physical and biological mechanisms influence the availability of prey for bowheads feeding near Barrow? Three related questions are (1) Where do the bowhead whales that feed near Barrow in late summer arrive from? (2) What is the residency time of feeding whales in the SNACS study area? and (3) Are feeding bowheads responding to new foraging opportunities coincident with climate change, or are they simply re-occupying habitat as the population increases, or have whales always used this area in late summer, but gone undetected for lack of survey effort? Each of these questions is discussed below, and additional details on the central SNACS question are provided in Ashjian et al. (2010).

The biophysical dynamics that lead to ideal whale foraging conditions near Barrow include wind forcing and tidal cycles acting on local prey fields (e.g., copepods and amphipods) and on prey (e.g., euphausiids) transported to the Barrow area from the North Pacific (Berline et al., 2008; Ashjian et al., 2010). Analyses of biophysical data obtained in the SNACS study area in 2005 and 2006 demonstrate significant interannual and shorter-term variability in the physical and biological conditions there. Short-term variability in hydrography was associated with changes in wind speed and direction, which profoundly affected the taxonomic composition of zooplankton on the shelf (see Ashjian et al., 2010: Figs. 9 and 10). Annual records of bowhead whale distribution from aerial surveys conducted each autumn from 1984 to 2004 demonstrate that large groups of whales are found most frequently in the SNACS region following periods of winds from the S or SE (Ashjian et al., 2010: Fig. 11). Combined, these observations support a conceptual model of the mechanisms that likely contribute to a favorable feeding environment for bowhead whales near Barrow (Ashjian et al., 2010: Fig. 14). In brief, sustained winds from the E or SE promote upwelling that brings whale prey onto the Beaufort shelf to the north and east of Barrow. When upwelling winds are followed by a 


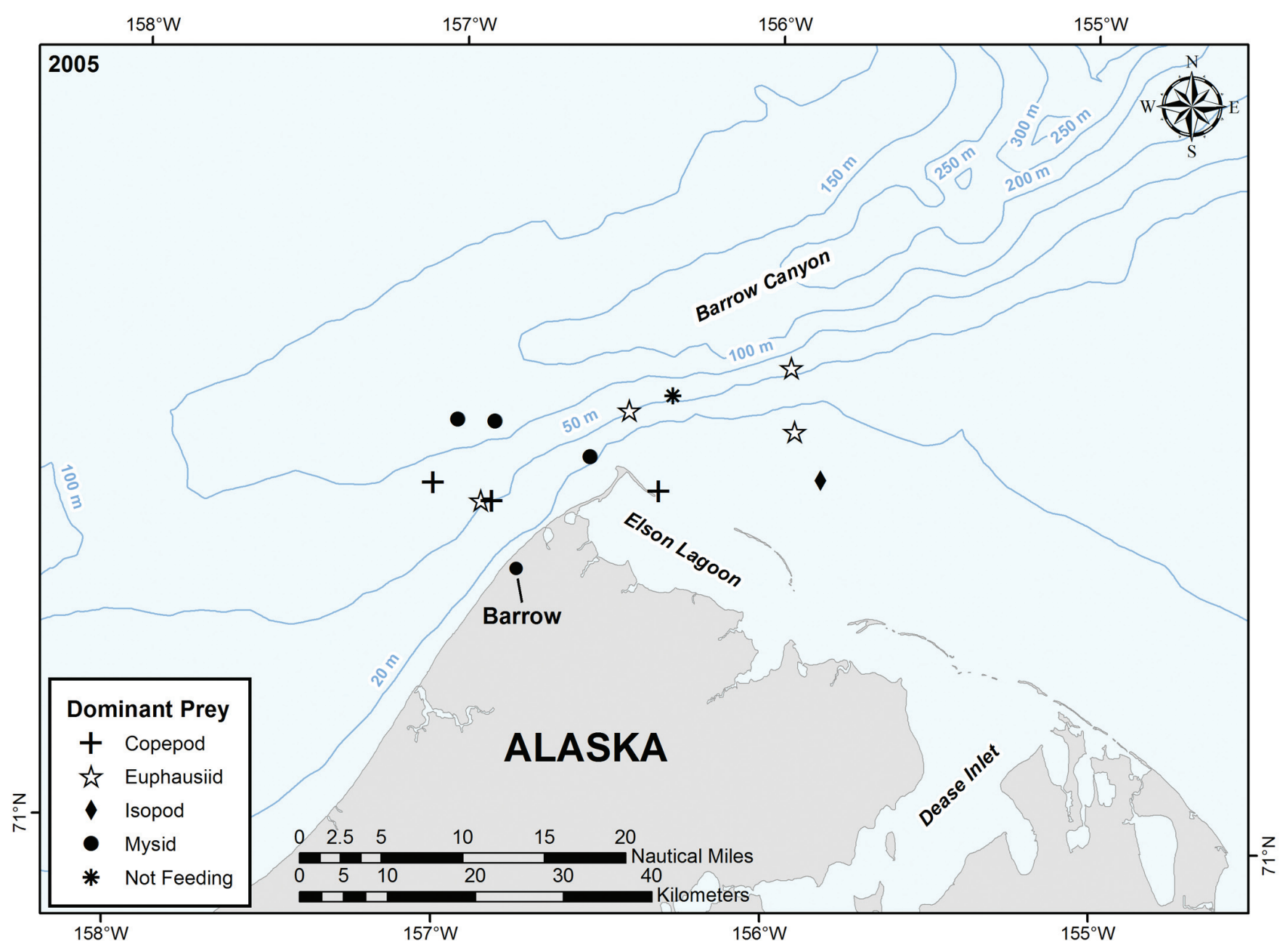

FIG. 4. Harvest location and dominant prey in the stomachs of bowhead whales taken near Barrow in autumn 2005.

period of weak winds or winds from the S, as was observed in early September 2006, euphausiids are concentrated on the shelf by the convergence of the westward flowing Beaufort current with the strong Alaska coastal current flowing along the Barrow Canyon. Our data are consistent with this model: most of the bowheads harvested on the shelf in 2006 had been feeding on euphausiids, while whales harvested near Barrow Canyon in 2005 contained more diverse prey.

The large group of bowhead whales seen near the barrier islands in 2005 included individuals that seemed to feed by simply lying on their sides with mouths agape. This observation fostered speculation that the lagoon might function as a prey reservoir. Support for the idea comes from observations that sustained winds from the E or SE can carry euphausiids across the shelf to the barrier islands, where sub-tidal fluxes of water flush them in and out of Elson Lagoon, as was seen in 2005 and 2006 (Okkonen, 2008; Ashjian et al., 2010). In this scenario, whales feed on euphausiids retained in and then transported out of the lagoon by outgoing tidal currents. The idea of the lagoon as a prey reservoir is consistent with frequent observations of windrows of euphausiids on beaches there and with the sightings of several thousand Arctic terns (Sterna paradisaea) within western Elson
Lagoon on 8 August 2006 (J.C. George, unpubl. data). The hypothesis is further supported by the correlation of wind velocity with the strength of sub-tidal flows through passages between the barrier islands of Elson Lagoon. In 2006, increased numbers of planktivorous birds were observed near lagoon outflows at passages near the downwind end of the lagoon (Okkonen, 2008).

In late summer, bowheads may arrive in the SNACS study area from the eastern Beaufort Sea, as the vanguard of the westward migration (Moore et al., 1989), or from the north, as suggested by some hunters. The combined sightings from 1 to 6 September 2006 (Fig. 2) demonstrate whales migrating into the study area from the east, supporting the first idea. Further support includes the northwesterly $\left(293^{\circ} \mathrm{T}, p<0.001\right)$ swimming direction of bowhead whales seen during late summer surveys conducted from 1979 to 1986 east of $150^{\circ} \mathrm{W}$ in the Beaufort Sea (Moore et al., 1989). However, local knowledge includes the idea that some bowhead whales summer north of Barrow, remaining near sea ice that often persists over continental slope and deep basin waters. These over-summering whales are described as large animals (Jonathan Aiken, Sr., pers. comm. 2005) that arrive near Barrow in late spring (June), "linger" offshore 


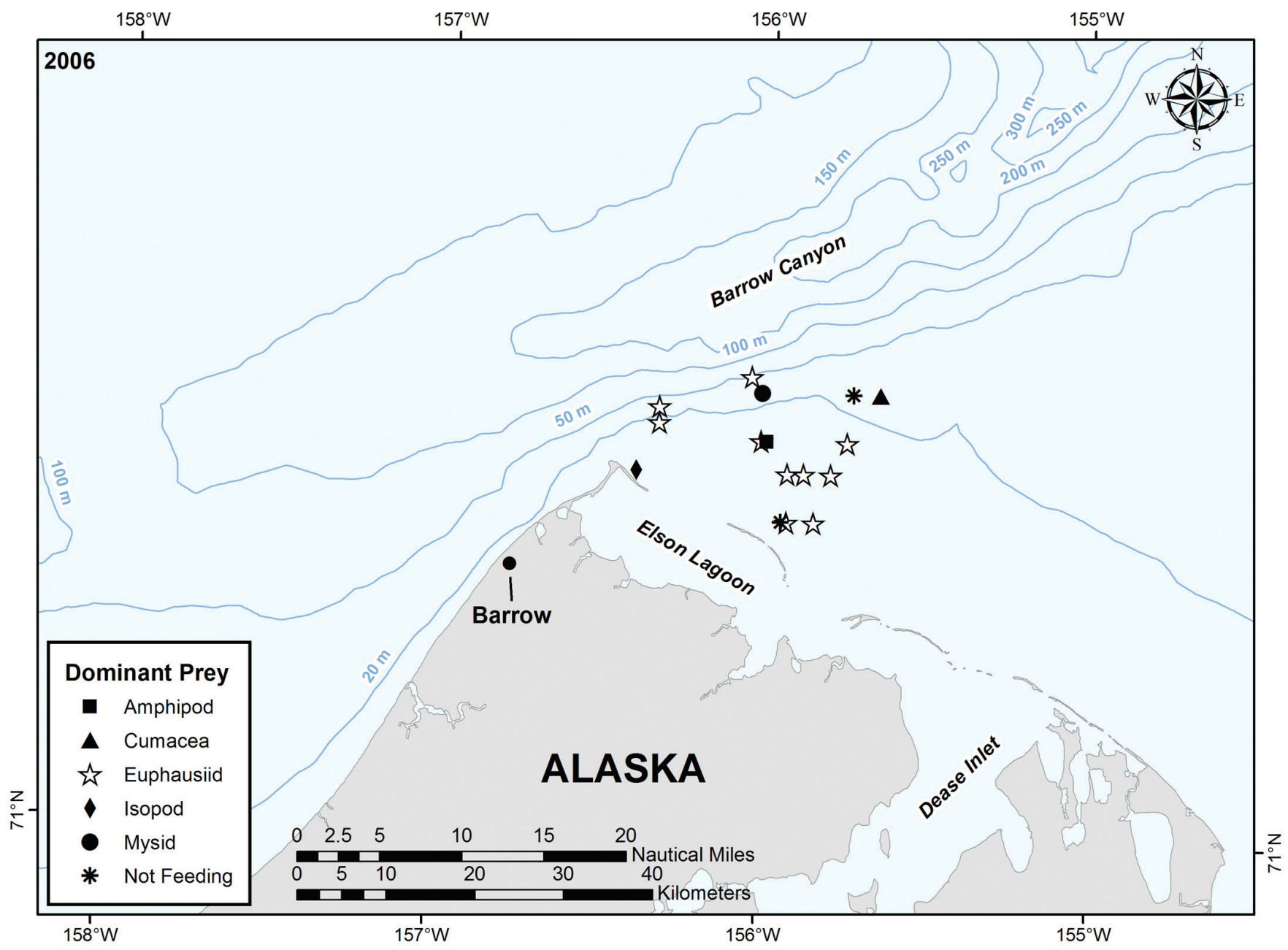

FIG. 5. Harvest location and dominant prey in the stomachs of bowhead whales taken near Barrow in autumn 2006.

rather than swimming east to the Canadian Beaufort Sea with the main herd, and then move towards shore and into the SNACS study area in late summer.

No matter where the whales arrive from, the residency time of bowheads in the SNACS study area is nearly impossible to assess from surveys alone. Aerial surveys during the SNACS study were limited to early September, and weather often curtailed flight effort. Aerial surveys conducted by the Minerals Management Service (MMS) in 2005 and 2006, and by contractors for the oil and gas industry in 2006, documented bowhead whales in the SNACS study area through October and into early November. Except in 2005, photoidentification of individual whales was not part of the survey programs, so there are few empirical data to evaluate individual whale residence times near Barrow.

The SNACS study identified feeding aggregations near Barrow in early September, roughly two weeks prior to aggregations reported from the 1970s through 1990s. So, are bowheads near Barrow in late summer responding to new feeding opportunities associated with climate change, or is a growing population (George et al., 2004) simply reoccupying habitat that it formerly used? Commercial whaling records suggest that bowheads were once common in the Chukchi Sea, including waters near Barrow, in late August (Bockstoce, 1986; Bockstoce et al., 2005: map 27). Hence recent observations may suggest a recovery in distribution concomitant with an increase in population. The fact that sea-ice cover during September-November has been decreasing in the Barrow area (Moore and Laidre, 2006) may also play a role in providing suitable foraging habitat. The extreme retreat of sea ice from the Alaskan coast seen by early September over the past decade (e.g., Serreze et al., 2007) provides conditions conducive to upwelling of basin water onto the continental shelf (Carmack and Chapman, 2003). If upwelling entrains prey, as suggested in our model, bowhead feeding habitat on the continental shelf will be enhanced. This idea is supported by the positive correlation between bowhead whale body condition and the reduction of sea ice in the eastern Beaufort Sea (George et al., 2005).

\section{SUMMARY}

Bowhead whales fed in late summer near Barrow, Alaska, in both 2005 and 2006. Feeding aggregations of 

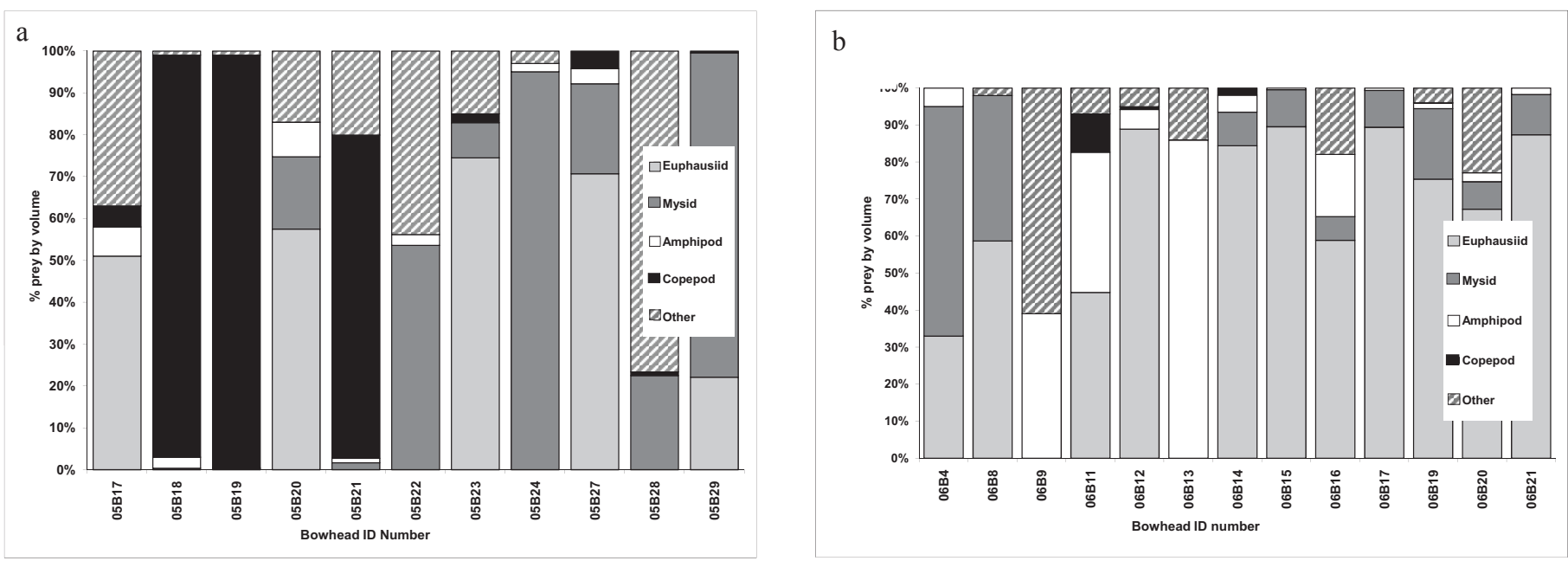

FIG. 6. Stomach contents for 24 bowhead whales, (a) 11 harvested in 2005 and (b) 13 harvested in 2006, showing proportions (by volume) of prey taxa.

40-70 whales occurred roughly two weeks earlier than similar aggregations reported in the 1970s to 1990s; this difference may be due to a reoccupation of summer habitat by a growing population of bowhead whales, or to a lack of dedicated surveys near Barrow in late summer in earlier decades. Although dominant prey taxa varied between years, the species found in whale stomachs often did not match the zooplankton sampled by oceanographers (Ashjian et al., 2010). While this mis-match is likely due to the different sample timing, it also suggests that feeding whales are more adept than oceanographers with nets at finding zooplankton swarms. This is especially true in very shallow water, or when zooplankton occurs very near the bottom, as sampling with nets is extremely difficult under these conditions. Nevertheless, observations from the SNACS study and retrospective analyses enabled us to develop a conceptual model of the mechanisms that result in prey availability for bowhead whales near Barrow in autumn. Continued multidisciplinary research, such as the ongoing Bowhead Whale Feeding Ecology Study (BOWFEST) (http://www.afsc. noaa.gov/NMML/cetacean/bwasp/flights_BOWFEST.php), provides opportunities to refine this model and to assess the effects of biophysical variability on bowhead whales during a period of rapid transition in this coastal Arctic ecosystem.

\section{DEDICATION}

We dedicate this paper to Mr. Ralph Aiken, an enthusiastic pilot with whom we were honored to conduct our surveys. We miss his good humor and friendship.

\section{ACKNOWLEDGEMENTS}

We thank the SNACS (Study of Northern Alaska Coastal Systems) team-Stephen Braund, Robert Campbell, Jack Kruse, Wieslaw Maslowski, Craig Nicolson, Stephen Okkonen, Barry Sherr, Evelyn Sherr, and Yvette Spitz-for their contribution to the overall study, of which this paper is but one part. Much of the field portion of this work was supported by the NSF/SNACS program. We appreciate the support and advice of the Barrow Whaling Captain's Association (BWCA) and the staff of the North Slope Borough (NSB) Department of Wildlife Management (DWM). Robert Suydam (NSB DWM) provided funding for additional aerial survey hours in 2005, and Chuck Monnett (Minerals Management Service, Alaska Region) shared the MMS aircraft with the SNACS project in 2006, making aerial surveys possible. We thank Julie Mocklin, Kim Shelden, and Kim Goetz (NOAA/National Marine Mammal Laboratory) for participation in the 2006 aerial surveys and for map preparation. Review comments from W. John Richardson (LGL Limited), Lloyd Lowry $(\mathrm{ADF} \& \mathrm{G}$, retired), and an anonymous reviewer greatly improved the final manuscript.

\section{REFERENCES}

Ashjian, C.J., Braund, S.R., Campbell, R.G., George, J.C., Kruse, J., Maslowski, W., Moore, S.E., et al. 2010. Climate variability, oceanography, bowhead whale distribution, and Iñupiat subsistence whaling near Barrow, Alaska. Arctic 63(2): 179-194.

Berline, L., Spitz, Y.H., Ashjian, C.J., Campbell, R.G., Maslowski, W., and Moore, S.E. 2008. Euphausiid transport in the western Arctic Ocean. Marine Ecology Progress Series 360:163-178.

Bluhm, B.A., and Gradinger, R. 2008. Regional variability in food availability for Arctic marine mammals. Ecological Applications 18(2) Suppl.:S77-S96.

Bockstoce, J.R. 1986. Whales, ice, and men. Seattle: University of Washington Press.

Bockstoce, J.R., Botkin, D.B., Philp, A., Collings, B.W., and George, J.C. 2005. The geographic distribution of bowhead whales, Balaena mysticetus, in the Bering, Chukchi, and Beaufort seas: Evidence from whaleship records, 1849-1914. Marine Fisheries Review 67(3):1-43.

Burns, J.J. 1993. Epilogue. In: Burns, J.J., Montague, J.J., and Cowles, C.J., eds. The bowhead whale. Society for Marine 
Mammalogy, Special Publication No. 2. Lawrence, Kansas: Allen Press. 745-764.

Carmack, E., and Chapman, D.L. 2003. Wind driven shelf/basin exchange on an Arctic shelf: The joint roles of ice cover extent and shelf-basin bathymetry. Geophysical Research Letters 30: GL017526.

George, J.C., Zeh, J., Suydam, R., and Clark, C. 2004. Abundance and population trend (1978-2001) of western Arctic bowhead whales surveyed near Barrow, Alaska. Marine Mammal Science 20(4):755-773.

George, J.C., Nicolson, C., Drobot, S., Maslanik, J., and Suydam, R. 2005. Sea ice density and bowhead whale body condition: Preliminary findings. Abstract only. 16th Biennial Conference of the Society for Marine Mammalogy, 12-15 December, San Diego, California.

Ireland, D.S., Funk, D.W., Rodrigues, R., and Koski, W.R., eds. 2008. Joint monitoring program in the Chukchi and Beaufort seas, July-November 2007. Report from LGL Alaska Research Associates, Inc., LGL Ltd., JASCO Research, Ltd. and Greeneridge Sciences, Inc. for Shell Offshore, Inc., ConocoPhillips Alaska, Inc., National Marine Fisheries Service, and the U.S. Fish and Wildlife Service. LGL Alaska Report P971-1. 445 p. + appendices.

Lambertsen, R., Rasmussen, K.J., Lancaster, W.C., and Hintz, R.J. 2005. Characterization of the functional morphology of the mouth of the bowhead whale and its implications for conservation. Journal of Mammalogy 86(2):342 - 352.

Landino, S.E., Treacy, S.D., Zerwick, S.A., and Dunlap, J.B. 1994. A large aggregation of bowhead whales (Balaena mysticetus) feeding near Point Barrow, Alaska, in late October 1992. Arctic 47(3):232-235.

Ljungblad, D.K., Moore, S.E., and Clark, J.T. 1986. Assessment of bowhead whale (Balaena mysticetus) feeding patterns in the Alaska Beaufort and northeastern Chukchi seas via aerial surveys, Fall 1979-84. Report of the International Whaling Commission 36:265-272.

Lowry, L.F. 1993. Foods and feeding ecology. In: Burns, J.J., Montague, J.J., and Cowles, C.J., eds. The bowhead whale. Society for Marine Mammalogy, Special Publication No. 2. Lawrence, Kansas: Allen Press. 201-238.

Lowry, L.F., and Frost, K.J. 1984. Foods and feeding of bowhead whale in western and northern Alaska. Scientific Report of the Whales Research Institute 35:1-16.

Lowry, L.F., Sheffield, G., and George, J.C. 2004. Bowhead whale feeding in the Alaskan Beaufort Sea, based on stomach contents analyses. Journal of Cetacean Research and Management $6: 215-223$.

Monnett, C., and Treacy, S.D. 2005. Aerial surveys of endangered whales in the Beaufort Sea, Fall 2002-2004. Outer Continental Shelf (OCS) Study MMS 2005-037. Anchorage, Alaska: Minerals Management Service, Alaska OCS Region.

Moore, S.E. 1992. Summer records of bowhead whales in the northeastern Chukchi Sea. Arctic 45(4):398-400.

Moore, S.E., and Laidre, K.L. 2006. Trends in sea ice cover within habitats used by bowhead whales in the western Arctic. Ecological Applications 16(3):932-944.
Moore, S.E., and Reeves, R.R. 1993. Distribution and movement. In: Burns, J.J., Montague, J.J., and Cowles, C.J., eds. The bowhead whale. Society for Marine Mammalogy, Special Publication No. 2. Lawrence, Kansas: Allen Press. 313-386.

Moore, S.E., Clarke, J.T., and Ljungblad, D.K. 1989. Bowhead whale (Balaena mysticetus) spatial and temporal distribution in the central Beaufort Sea during late summer and early fall 1979-86. Report of the International Whaling Commission 39:283-290.

Moore, S.E., DeMaster, D.P., and Dayton, P.K. 2000. Cetacean habitat selection in the Alaska Arctic during summer and autumn. Arctic 53(4):432-447.

Okkonen, S.R. 2008. Exchange between Elson Lagoon and the nearshore Beaufort Sea and its role in the aggregation of zooplankton. Final Report. OCS Study MMS 2008-010. Anchorage, Alaska: Minerals Management Service, Alaska OCS Region. 19 p.

Ragen, T.J., Huntington, H.P., and Hovelsrud, G.K. 2008. Conservation of Arctic marine mammals faced with climate change. Ecological Applications 18(2) Suppl.:S166-S174.

Richardson, W.J., and Malme, C.I. 1993. Man-made noise and behavioural responses. In: Burns, J.J., Montague, J.J., and Cowles, C.J., eds. The bowhead whale. Society for Marine Mammalogy, Special Publication No. 2. Lawrence, Kansas: Allen Press. 631-700.

Rugh, D., DeMaster, D., Rooney, A., Breiwick, J., Shelden, K., and Moore, S. 2003. A review of bowhead whale stock identity. Journal of Cetacean Research and Management 5(3):267-279.

Serreze, M.C., Holland, M.M., and Stroeve, J. 2007. Perspectives on the Arctic's shrinking sea-ice cover. Science 315: $1533-1536$

Stoker, S.W., and Krupnik, I.I. 1993. Subsistence whaling. In: Burns, J.J., Montague, J.J., and Cowles, C.J., eds. The bowhead whale. Society for Marine Mammalogy, Special Publication No. 2. Lawrence, Kansas: Allen Press. 579-629.

Suydam, R.S., Angliss, R.P., George, J.C., Braund, S.R., and DeMaster, D. 1995. Revised data on the subsistence harvest of bowhead whales (Balaena mysticetus) by Alaska Eskimos, 1973 - 1993. Report of the International Whaling Commission 45:335-338.

Thomson, D.H. 2002. Energetics of bowhead whales. In: Richardson, W.J., and Thomson, D.H., eds. Bowhead whale feeding in the eastern Alaskan Beaufort Sea: Update of scientific and traditional information. OCS Study MMS 2002-012; LGL Report TA2196-7. Report from LGL Ltd. Environmental Research Associates, King City, Ontario, for U.S. Minerals Management Service. 22-1-22-40. http://www. mms.gov/alaska/reports/2002rpts/akpubs02.htm.

Wang, M., and Overland, J.E. 2009. A sea ice free summer Arctic within 30 years? Geophysical Research Letters 36, L07502, doi:10.1029/2009GL037820.

Würsig, B., and Clark, C. 1993. Behaviour. In: Burns, J.J., Montague, J.J., and Cowles, C.J., eds. The bowhead whale. Society for Marine Mammalogy, Special Publication No. 2. Lawrence, Kansas: Allen Press. 157-200. 